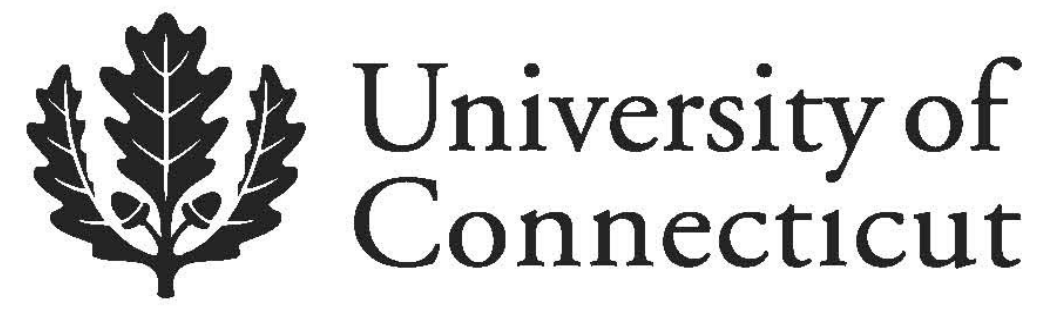

Department of Economics Working Paper Series

\title{
Political Legitimacy and Technology Adoption
}

Metin M. Coşgel

University of Connecticut

Thomas J. Miceli

University of Connecticut

Jared Rubin

Chapman University

Working Paper 2011-28

December 2011

341 Mansfield Road, Unit 1063

Storrs, CT 06269-1063

Phone: (860) 486-3022

Fax: (860) 486-4463

http://www.econ.uconn.edu/

This working paper is indexed on RePEc, http://repec.org/ 


\title{
Political Legitimacy and Technology Adoption*
}

\author{
Metin M. Coşgel ${ }^{\dagger}$, Thomas J. Miceli ${ }^{\ddagger}$, and Jared Rubin ${ }^{\S}$
}

\begin{abstract}
A fundamental question of economic and technological history is why some civilizations adopted new and important technologies and others did not. In this paper, we construct a simple political economy model which suggests that rulers may not accept a productivity-enhancing technology when it negatively affects an agent's ability to provide the ruler legitimacy. However, when other sources of legitimacy emerge, the ruler will accept the technology as long as the new legitimizing source is not negatively affected. This insight helps explain the initial blocking but eventual accepting of the printing press in the Ottoman Empire and industrialization in Tsarist Russia.
\end{abstract}

Journal of Economic Literature Classification: D7, H2, H3, N4, N7, O3, O5, P48, P5, Z12

Keywords: technology, political economy, legitimacy, Tsarist Russia, Ottoman Empire

\footnotetext{
${ }^{*}$ We are grateful to Steven Nafziger for valuable comments. All errors are our own.

${ }^{\dagger}$ Professor of Economics, University of Connecticut, Storrs, CT 06269-1063, Ph: (860) 486-4662, Fax: (860) 4864463, e-mail: metin.cosgel@uconn.edu

${ }^{\ddagger}$ Professor of Economics, University of Connecticut, Storrs, CT 06269-1063, Ph: (860) 486-5810, Fax: (860) 4864463, e-mail: thomas.miceli@uconn.edu

$\S$ Assistant Professor of Economics, Chapman University, Orange, CA 92866, Ph. (714) 516-4530, Fax: (714) 5326081, e-mail: jrubin@chapman.edu
} 


\section{INTRODUCTION}

Why and when are new technologies accepted or not accepted? The answer to this question has important implications for world economic history - the acceptance and diffusion of new technologies generally goes hand-in-hand with economic development, while non-acceptance often leads to stagnation (Olsen 1982; Mokyr 1990; Landes 1998). A satisfactory answer must explain not only why some societies suppress new technologies, but also why others initially block technologies but eventually accept them. That is, purely cultural arguments have difficulty explaining technology adoption - why would culture encourage blocking of technology in some instances but acceptance in others?

In this paper, we suggest that there are broader institutional determinants of technology adoption. We consider two important historical examples of failures to adopt new and important technologies: the Ottoman blocking of the printing press in the fifteenth through seventeenth centuries and Russia's failure to industrialize prior to and directly after the Crimean War. We analyze these cases in the context of a simple political economy model centered on the legitimizing relationship between rulers, legitimizing agents, and the general public. ${ }^{1} \mathrm{We}$ develop an analytical framework to capture the basic elements of the strategic interaction between rulers and legitimizing authorities (e.g., religious, military, or bureaucracy). The model suggests that rulers may choose not to accept new, productivity-enhancing technologies if these technologies sufficiently damage their ability to be legitimized by their agents, which in turn diminishes their ability to collect taxes. This occurred, for example, in the Ottoman case as the printing press would have undermined the monopoly held by religious authorities on the reproduction of ideas and the transmission of the Qur'an. Likewise, the delayed industrialization

\footnotetext{
${ }^{1}$ Similar models that explore this legitimizing relationship include Coşgel, Miceli, and Ahmed 2009; Coşgel, Miceli, and Rubin 2011; Rubin 2011.
} 
of Tsarist Russia occurred in part because it would have diminished the political and social importance of the nobility - many of whom held key bureaucratic roles while profiting primarily from serf agriculture, not industry. However, when alternative forms of legitimacy arise that are not harmed by the new technology, rulers have more incentive to accept new technologies. In the Ottoman case, notables emerged as an alternative means of extracting taxes, and the sultans were thus less dependent on loyalty supplied by religious authorities. This lowered the cost of accepting the printing press, which was fully adopted by the Ottomans in the nineteenth century. In Tsarist Russia, the bureaucracy changed in the decades following the Crimean War to one less composed of landed interests, in turn entailing a decreased resistance to industrialization (which was eventually accepted in the last two decades of the nineteenth century). In both cases under study, the alternative form of legitimacy was ambivalent to the new technology and did not actively pressure the ruler to accept it. Instead we argue that their role in technology adoption was that they displaced sources of legitimacy that actively pressured the ruler to forbid the technology.

There is a vast literature analyzing the determinants of technology adoption. One strand extends the insights of the literature on interest group politics, suggesting that resistance to technology adoption is a rational response by potential economic "losers". For example, Mokyr (1990, 1992, 1998) provides numerous historical examples of such resistance, including the Luddites damaging British looms, the European craft-guilds freezing the technological status quo, and French armorers resisting the use of interchangeable parts in the musket-making trade in the years before and during the French Revolution. Mokyr suggests that sources of rational resistance include unemployment (via labor-saving technological change), non-pecuniary losses (such as workplace safety or noise), and human capital (making the skills of older workers 
obsolete). Krusell and Ríos-Rull (1996) and Bellettini and Ottaviano (2005) analyze the latter source in a theoretical framework, proposing that "vested interests", particularly older workers who have made human capital investments in the prevailing technology regime, can temporarily block technological change in simple political settings (resulting in long cycles of stagnation and growth). ${ }^{2}$

Other models, which are closer to the one we present in this paper, emphasize the role of political losers in blocking innovation. ${ }^{3}$ Acemoglu and Robinson $(2000,2006)$ argue that when new and productive technologies sufficiently erode political advantages and future economic rents of elites or enrich rival groups, political elites will block them in order to stabilize - and maintain their place in - the existing system. In particular, they propose that elites who face a high degree of competition (and are thus likely to be replaced) or are greatly entrenched (and not likely to be replaced) will support productive innovation - it is elites who are "somewhat entrenched but still fear replacement" who have the greatest incentive to block technology adoption. They suggest that this can explain the opposition to industrialization by Russian Tsars and Hapsburg elites in Austria-Hungary (whose power was not totally secure) but not by elites in Britain or Germany (who were sufficiently entrenched). In a similar vein, Chaudhry and Garner (2007) model adoption of technologies which may be harmful to the government (i.e., decreasing its probability of staying in power), finding that that probability of "innovation blocking" is

\footnotetext{
${ }^{2}$ Similar contributions emphasizing the role of economic "losers" include Parente and Prescott (1999), who claim that regulations supporting monopoly rights drive failures to adopt superior technologies. Bridgman et al. (2007) argue that technology is likely to be blocked by small groups of skilled incumbents who can overcome free-rider and collective action problems (even when the technology makes all workers less productive). Canton et al. (2002) suggest that older workers are less likely to adopt new technologies since the future gains do not outweigh the perceived adoption costs.

${ }^{3}$ A third strand of literature emphasizes the importance of path-dependence and network externalities on the nonadoption of more efficient technologies and, in particular, the adoption of (relatively) inefficient technologies. See, for example, David (1985) and Katz and Shapiro (1986). A nice overview of the extensive industrial organization literature concerned with the decision of firms to adopt new technologies at certain points in time - a concern outside the scope of our argument - is provided by Hoppe (2002).
} 
increasing in the probability of losing power following innovation, the degree of rent seeking by the government, and the cost of implementing innovation blocking. ${ }^{4}$

Yet, all of these models consider the factors affecting innovation blocking (e.g., the degree of ruler entrenchment and rent-seeking) to be exogenous to the choice of adoption. That is, no existing model accounts for the salient interactions between institutions or other players who are likely to determine the degree to which innovation is "harmful" to the political authority. Our model expands on the existing literature by taking into account how the interactions between rulers and legitimizing agents under varying institutional settings affect the choice of technology adoption.

We also contribute to the literature a specific process through which societies may eventually adopt (or, not oppose) previously suppressed technologies. Previous approaches have typically attributed the eventual adoption of technologies to external shocks, such as a lost war, that set off significant changes in social attitudes toward technologies or in the political equilibrium of vested interests. Whereas these explanations often leave it unspecified how exactly external shocks spread through the system, we incorporate these events into a coherent whole and elaborate on how internal and external factors altered legitimizing relationships and caused rulers to reverse policy.

\section{THE MODEL: TECHNOLOGY ADOPTION AND LEGITIMACY}

The model involves a game played between a ruler, the citizenry, and two players who legitimize the ruler. The latter players could represent a religious authority, a military authority, or an aristocratic class (nobility). The citizenry consists of a representative worker who produces

\footnotetext{
${ }^{4}$ Chaudhry and Garner (2006) present a similar model linking the presence of rival states (which affects the ruler's ability to retain power) to the acceptance of technology and innovation.
} 
output with an input of capital, $k$, using the production function $f(\theta k)$, where $\theta$ is a parameter reflecting the prevailing technology, and $f^{\prime}>0, f^{\prime \prime}<0$. Let the unit cost of capital be $r$, so that net output is

$$
f(\theta k)-r k
$$

The objective of the ruler is to extract as much of net output from the worker as possible for his private consumption. To do so, it assesses a lump sum tax, $T .^{5}$ Thus, the worker's utility, given by his residual wealth, is

$$
U=f(\theta k)-r k-T
$$

His utility-maximizing choice of capital thus solves the first order condition

$$
\theta f^{\prime}=r
$$

which defines the capital input as a function of the technology, $k^{*}(\theta)$. It is easy to verify that, given $f^{\prime \prime}<0, k^{*}$ is increasing in $\theta$, as is net output in (1). Thus, any improvement in technology (as measured by an increase in $\theta$ ) is socially valuable.

The ruler sets the tax at the level that just allows the worker to achieve his reservation utility, $\bar{U}$, which can be interpreted as the minimum level of wealth that would forestall a revolt. From (2), we therefore obtain the tax function

$$
T(\theta)=f\left(\theta k^{*}(\theta)\right)-r k^{*}(\theta)-\bar{U}
$$

Clearly, this function is also increasing in $\theta$.

We assume that tax collection is costly, reflecting the resistance of workers to the coercive seizure of their wealth. Specifically, suppose that a fraction of total collected taxes are dissipated. This could be due to efforts by workers to conceal wealth, corruption by tax collectors, or simply violence in the collection process. Let $\delta(L)$ be the fraction of lost taxes,

\footnotetext{
${ }^{5}$ The tax is assumed to be lump sum only for analytical simplicity. The basic results would not be affected by a proportional tax.
} 
where $L$ is defined to be the "legitimacy" of the ruler. Since workers will be less resistant to rulers who are seen as being more legitimate, we assume that $\delta^{\prime}<0$.

Assume that the ruler derives legitimacy from two sources, $A$ and $B$, which provide units of legitimacy $x_{A}$ and $x_{B}$. The ability of these sources to legitimize is a function of the technology. Legitimacy is determined by a Cobb-Douglas production function with elasticity parameters $\alpha>$ 0 and $\beta>0$, where $\alpha+\beta \leq 1$, so that:

$$
L=\left(\theta^{\gamma} x_{A}\right)^{\alpha}\left(\theta^{\eta} x_{B}\right)^{\beta}
$$

The parameters $\gamma$ and $\eta$ are elasticity measures of how technology affects $A$ and $B$ as legitimizing sources. That is, if $\gamma<0$, a technological change hurts the ability of $A$ to legitimize, whereas $\gamma>$ 0 means that a technological change improves the ability of $A$ to legitimize. The same can be said for $\eta$ in relation to $B .^{6}$

Suppose the ruler is able to "purchase" units of legitimacy from $A$ and $B$ at cost $w_{A}$ and $w_{B}$. This could reflect the cost of maintaining a standing army (force) or a scholarly/religious community (indoctrination) whose role is to legitimize the ruler. ${ }^{7}$ The prevailing technology is assumed to be relevant for tax collection in the sense that it may either facilitate or inhibit the legitimization function. For example, technological advancements that improve the military would presumably enhance legitimacy by making tax collection easier, whereas advancements like the printing press might make resistance more likely by undermining the ability of religious authorities to legitimize. To capture both possibilities, we allow $\gamma$ and $\eta$ to be either positive (facilitating) or negative (inhibiting).

\footnotetext{
${ }^{6}$ Note that an alternative specification where the ruler is uncertain of the degree to which technology affects legitimacy or is uncertain of the degree to which purchasing legitimacy will affect his ability to extract taxes, the qualitative results remain as long as the ruler is risk averse and knows the sign of $\gamma$ and $\eta$.

${ }^{7} \mathrm{We}$ only employ a partial-equilibrium model, as the costs of legitimacy are exogenously determined. A more complete model would have these costs determined endogenously as a function of technology. However, as long as technology affects costs in the same way that it affects the efficacy of the legitimizing agent, the qualitative results of the simpler model presented here are the same as a full-equilibrium model.
} 
Finally suppose the ruler potentially faces an external threat, such as the risk of an attack from a foreign country that could result in his overthrow. Let $p(\theta)$ be the probability that he retains control in the face of this threat, where we assume that $p^{\prime}>0$, reflecting the fact that improvements in technology will likely increase his chances of fending off foreign threats (Acemoglou and Robinson 2006).

The optimization problem for the ruler is to choose $x_{A}$ and $x_{B}$ to maximize his net return, given by:

$$
R=p(\theta) T(\theta)(1-\delta(L(\theta)))-w_{A} x_{A}-w_{B} x_{B}
$$

The first order conditions are

$$
\begin{aligned}
& -p(\theta) \alpha T(\theta) \delta^{\prime}(L) \theta^{\alpha \gamma+\beta \eta} x_{A}{ }^{\alpha-1} x_{B}^{\beta}=w_{A}, \\
& -p(\theta) \beta T(\theta) \delta^{\prime}(L) \theta^{\alpha \gamma+\beta \eta} x_{A}{ }^{\alpha} x_{B}{ }^{\beta-1}=w_{B},
\end{aligned}
$$

which define $x_{A} *(\theta)$ and $x_{B} *(\theta)$. This also provides the following equilibrium level of legitimacy:

$$
L^{*}(\theta)=-w_{A} x_{A}^{*}(\theta) / p \alpha T \delta^{\prime}=-w_{B} x_{B}^{*}(\theta) / p \beta T \delta^{\prime} .
$$

The optimized value of the ruler's return as a function of the prevailing technology is

$$
R(\theta)=p(\theta) T^{*}(\theta)\left[1-\delta\left(L^{*}(\theta)\right)\right]-w_{A} x_{A}^{*}(\theta)-w_{B} x_{B} *(\theta) .
$$

Given this expression, we are interested in the ruler's decision about whether or not to adopt a new technology. If we interpret the new technology as an increase in $\theta$, this decision turns on the sign of the derivative of (10) with respect to $\theta$ (using the Envelope Theorem and deriving $\frac{\partial L^{*}}{\partial \theta}$ from (5)):

$$
\frac{\partial R}{\partial \theta}=p^{\prime} T^{*}(1-\delta)+p \frac{\partial T^{*}}{\partial \theta}(1-\delta)-\frac{p T^{*} \delta^{\prime} L^{*}}{\theta}(\alpha \gamma+\beta \eta)
$$


The first two terms are positive, reflecting, respectively, the positive impact of technology on the likelihood of retaining control and on tax collection. ${ }^{8}$ The sign of the third term, however, depends on how technology affects the legitimacy function. In particular, since $\frac{p T^{*} \delta^{\prime} L^{*}}{\theta}<0$, the decision to accept or reject the technology depends on the sign and magnitude of $\alpha \gamma+\beta \eta$, which is the elasticity of legitimacy with respect to technology. Note that this elasticity is comprised of four parts: $\alpha \gamma$ is the product of production-specific elasticity parameter $(\alpha)$ and the technology-specific elasticity parameter $(\gamma)$ for $x_{A}$, and $\beta \eta$ is the same product for $x_{B}$.

If $\alpha \gamma+\beta \eta>0$, meaning that elasticity of $L$ with respect to $\theta$ is positive, then (11) is positive, and the ruler clearly adopts the technology. It follows that there is some threshold level, call it $\varepsilon^{*}<0$, where any elasticity $\alpha \gamma+\beta \eta>\varepsilon^{*}$ means that the ruler adopts the technology, whereas $\alpha \gamma+\beta \eta<\varepsilon^{*}$ entails that the leader does not adopt the technology. Note that the latter case can only occur if the new technology negatively affects at least one of the source's ability to legitimize the ruler - that is, either $\gamma<0$ or $\eta<0$. From this analysis we derive the following proposition:

Proposition 1: $\quad$ The ruler will accept a new technology if and only if the elasticity of legitimacy with respect to new technology, $\alpha \gamma+\beta \eta$, is sufficiently large. There exists some threshold level $\varepsilon^{*}<0$ where the ruler does not accept the technology when $\alpha \gamma+\beta \eta<\varepsilon^{*}$ but does accept the technology when $\alpha \gamma+\beta \eta>$ $\varepsilon^{*}$.

Table 1 summarizes how changes in each parameter affect the likelihood of technology adoption. It indicates that the technology adoption decision is intimately related to the elasticity parameters. We show in the following sections that the value of these parameters is most strongly influenced by two factors: the direct effect of the technology on the economic, political,

\footnotetext{
${ }^{8}$ Using the envelope theorem, $\frac{\partial T^{*}}{\partial \theta}=k^{*} f^{\prime}\left(\theta k^{*}\right)$.
} 
or social standing of the legitimizing force and the availability of closely substitutable forms of legitimacy.

[INSERT TABLE 1 HERE]

\section{THE PRINTING PRESS IN THE OTTOMAN EMPIRE ${ }^{9}$}

The long delayed acceptance of the printing press in the Ottoman Empire provides an important historical example with which we can test our model. In 1485, within decades after the appearance of Gütenberg's first book published by moveable type in Germany, the Ottoman sultan is said to have issued an edict that banned printing in Ottoman Turkish (in Arabic characters). ${ }^{10}$ Ottoman rulers started to relax the ban in 1726 , but they continued to regulate printing by granting permission only to selected individuals, prohibiting publication in religious subjects, and appointing a committee of scholars to review and proofread contents for accuracy. $^{11}$

Since the Ottoman ban on mass printing has wide implications for Muslim attitudes towards Western technology and reasons for economic underdevelopment, a vast literature has developed to explain why the Ottomans regulated the printing press so heavily for so long. The generalist literature and Eurocentric approaches have focused on religious and cultural factors, such as religious conservatism and low demand for printed books (due to a preference for manuscripts), but no direct evidence has been offered to support these arguments systematically. Arguments emphasizing religious and cultural factors have generally lacked a coherent whole and have relied on ad hoc generalizations about how religious and cultural factors affect

\footnotetext{
${ }^{9}$ This section is abridged and amended from Coşgel, Miceli, and Rubin (2011).

${ }^{10}$ The authenticity of this edict has not been well-established. Although Mystakidis (1911: 324) mentioned the presence of such an edict in the first volume of Türk Tarih Encümeni Dergisi, the validity of this claim was quickly challenged by Efdaleddin (Tekiner) Bey in the same publication five years later on the grounds that Ottoman archives do not house edicts issued prior to 1553 and thus Mystakidis could not possibly have seen it. Either way, the absence of printed books dating from this period indicates that a ban was in place.

${ }^{11}$ See Atiyeh (1995: 284-5) for an English translation of the 1726 royal order.
} 
economic motivations and outcomes. ${ }^{12}$ Some historians have attributed the late adoption of printing press to the lack of appropriate technical skill in Ottoman society and the difficulties of printing in Arabic characters. ${ }^{13}$ These arguments have also failed to provide a complete explanation because the evidence suggests that the Ottomans had access to the expertise required to establish the technology and to solve technical problems. Religious minorities were allowed to set up their own presses with the provision that they could only print in non-Arabic characters. Jewish immigrants from Spain and Portugal, for example, were allowed to establish a press in Istanbul in 1493, soon publishing the Torah and other religious and secular texts in Hebrew characters (Gerçek, 1939: 26-29). Although the peculiarities of the Arabic script presented unique challenges, they were not insurmountable. Several parties had managed to print in Arabic characters outside of the Empire as early as the beginning of the sixteenth century. Several presses were established in Italy, Paris, and even Lebanon that were capable of printing in Arabic characters long before the Ottomans finally sanctioned the technology in the eighteenth century.

The rejection of the printing press presents an economic puzzle because it could have promoted economic growth and indirectly raised the ruler's tax revenues (that is, $\theta>0$ ). ${ }^{14} \mathrm{By}$ adopting the printing press soon after its introduction, the Ottomans would have improved economic productivity, thus raising the size of the revenue available to them for taxation. Although literacy was low, introducing the press would have ultimately increased productivity through positive externalities and its effect on human capital, as increased access to readable material would have encouraged investment in literacy.

\footnotetext{
${ }^{12}$ See, for example, Cipolla (1966), Jones (1987: Chapter 9), Goldschmidt (2002: Chapter 9), and Lewis (1982: Chapter 9). For a classic criticism of this approach, see Said (1978).

${ }^{13}$ For the history of the printing press in the Ottoman Empire and various explanations of the delay in adopting it, see Adıvar (1943: Ch. 6), Gerçek (1939), Kut (1991), Robinson (1993), Sabev (2006), Savage-Smith (2003), and Szyliowicz (1986).

${ }^{14}$ There is significant evidence that the printing press directly contributed to economic growth in Europe. See, amongst many others, Eisenstein (1979), Baten and van Zanden (2008), and Dittmar (2011).
} 
The model suggests that one reason that Ottoman sultans resisted mass printing in Ottoman Turkish was due to its effect on their sources of legitimacy. In this period, the sultans attained legitimacy necessary to extract taxes through two sources, the religious establishment $(A)$ and tax collectors/farmers $(B)$. In the fifteenth through seventeenth centuries, the military was used extensively in tax collection. Under a prebendal mechanism of tax collection called the timar system, provincial cavalrymen (sipahis) collected taxes directly from the peasantry as remuneration for their military services to the state. The military increasingly became involved in some capacity in tax-farming and in the collection of occasional taxes called the avartz and various other tax revenues for provincial offices or the central treasury (Darling, 1996: Chapter 5). ${ }^{15}$ Indeed, Coşgel, Miceli, and Rubin (2011) suggest that this was a primary reason why the Ottomans so eagerly accepted Western military technologies.

On the other hand, religious authorities could confer legitimacy through a different mechanism than that used by military authorities, namely loyalty. This mechanism was a process through which religious authorities encouraged the citizens to believe that the Ottoman sultan had the right to rule and the power to provide protection and other public goods and services and that he should therefore have the right to collect taxes. Given the power of religious belief, their word could have provided a single, coherent, and effective source of legitimacy (Greif 2002).

In early modern Ottoman society, prior to the introduction of the printing press, religious authorities had a monopoly in providing legitimacy through loyalty because the transmission of knowledge depended on oral technology, and the authorities had a vast comparative advantage in this type of transmission. The production of loyalty was a labor intensive process through which

\footnotetext{
${ }^{15}$ For example, according to tax-farming registers of 1603-4, almost two-thirds of tax-farmers were of military origin (Darling, 1996: 179).
} 
religious authorities could support the ruler or the state through sermons and speeches delivered as part of their official function. They also assisted the rulers in controlling the limited number of books available for public use in libraries, scrutinizing their contents, and ensuring the suppression of items that could threaten loyalty (Göçek, 1987: 109). To ensure the stability of loyalty-based legitimacy, Ottoman rulers incorporated legal and religious institutions into the state bureaucracy and sought to control religious authorities by supporting them financially and acquiring the right to appoint their leaders (Coşgel, Miceli, and Ahmed, 2009).

Mass printing in Ottoman Turkish was potentially a significant threat to the stability of this process and to the ability of religious authorities to provide legitimacy. In terms of the model, $\gamma$ was significantly less than zero - that is, the introduction of the new technology greatly damaged the religious authorities' ability to legitimize the sultan. Once adopted, mass printing would have altered the technology of transmitting knowledge and diminished the comparative advantage of religious authorities. The authorities could have lost their monopoly in the transmission of knowledge and their power in convincing the public about the legitimacy of the ruler. As developments around the world later showed, such fears were well-founded because mass printing gradually led to a decline in the comparative advantage of religious authorities in both Europe and the Islamic world (Eisenstein, 1979; Robinson, 1993: 245-46). On the other hand, the introduction of the press had little direct effect on the military's ability to legitimize the ruler $(\eta)$. It did have an indirect effect, however, which emerged from the complementarity between the military and religious authorities as sources of legitimacy. Where the ruler was viewed as legitimate in the eyes of God, the amount of force necessary to coerce taxes from the populace was lower. Thus, in terms of the model, the introduction of the printing press indirectly increased the tax-collecting efficacy of the military $(\eta)$. 
It was therefore in the best interest of the Ottoman sultans to regulate the printing press heavily. First, $\alpha \gamma$ (the religious-specific elasticity) was quite negative in this period, as the sultans depended on religious authorities for legitimacy ( $\alpha$ was large $)^{16}$ and the technology-specific elasticity $(\gamma)$ was large and negative. Moreover, accepting the printing press would have decreased the efficacy of the military authority ( $\eta$ was negative), since religious and military authorities were complementary legitimizing sources. Since the Ottoman tax collection system was based on force, $\beta$ was large and positive and thus the total military-specific legitimacy $(\beta \eta)$ was large and negative. Combined, these two features suggest that the $15^{\text {th }}-17^{\text {th }}$ century Ottoman sultans faced a situation where the elasticity of legitimacy with respect to new technology, $\alpha \gamma+$ $\beta \eta$, was significantly negative, and the sultan's optimal choice was to ban the printing press.

The Ottomans eventually lifted the ban on the printing press in 1726, giving exclusive rights to certain individuals to print in Ottoman Turkish. Following a shaky, intermittent, and heavily regulated presence in the eighteenth century, during which only 33 books were published, the industry grew fast in the nineteenth century. The ban on Islamic subjects printing books was lifted in 1802, and the lithographic press was adopted soon after its invention in Germany. In the decade following the creation of Takvimhane-i Âmire in 1831 to print the first official newspaper, six new presses were founded, publishing a total of 278 books. Sixty (22\%) of these books were on religious subjects. Thirteen new presses were launched in the next decade, altogether publishing a total of 394 books (31\% on religious subjects). ${ }^{17}$ The industry was well-established by the mid-nineteenth century, with the state getting actively involved through school books, official newspapers, and various administrative publications.

\footnotetext{
${ }^{16}$ For more on this legitimizing relationship, see Coşgel, Miceli, and Ahmed (2009) and Rubin (2011).

${ }^{17}$ Calculated from the information presented in Baysal (1968: 40-42).
} 
What can explain this change in Ottoman policy? One possibility could be that a significant external event, such as a lost war against western powers, might have altered the attitudes of Ottoman sultans and the general public towards western technology, making them more open to change. ${ }^{18}$ This argument has been variously made in the literature on Ottoman westernization, where military losses at the end of the seventeenth century are viewed as the catalyst for changing attitudes towards the West in Ottoman society and administration. ${ }^{19}$ This is consistent with the effect of external effects as specified in the model through $p(\theta)$ namely the probability that the ruler would retain control in the face of a threat that could result in his overthrow (Acemoglou and Robinson 2006). To fend off such a threat the Sultan might have adopted western technologies including the printing press.

While this may be a reasonable description of the general relationship between external threats and technology adoption, there are significant gaps in the specific causality between lost wars and the printing press in the Ottoman case. There is, for example, a significant gap in the timing of significant wars and the acceptance of printing in Ottoman Turkish, a gap that needs to be carefully filled for a satisfactory explanation. The event that is typically identified as the most significant external shock of the seventeenth century is the failed second siege of Vienna (1683), which happened over forty years before the lifting of the ban on printing in Ottoman Turkish. There was also the famous Karlowitz treaty (1699) that ratified territorial losses and various other wars that took place closer to the adoption of the printing press, but including these other events in the set of external shocks makes the overall explanation even more ad hoc, raising the question of which of these events was more important than others and how exactly they affected the attitudes and policies of Ottoman sultans.

\footnotetext{
${ }^{18}$ We thank an anonymous referee for this argument.

${ }^{19}$ For examples of this argument, see Güçek (1987: 3-6) and Neumann (2006: 54-56).
} 
Maintaining our focus on legitimizing relationships and being more specific about the underlying processes, we argue that two fundamental institutional changes occurred in the $17^{\text {th }}$ through $19^{\text {th }}$ centuries that significantly changed the ruler's decision-making calculus through their effect on legitimizing relationships. First, there was a significant change in the internal organization of the religious establishment beginning in the seventeenth century, particularly in appointments and incentives. Appointment was increasingly centralized during this period, with recruits coming primarily from schools in Istanbul rather than provinces, promotions being based on connections and wealth rather than merit or seniority, and prominent families dominating the highest ranks over several generations. Privilege was institutionalized in an aristocratic organization, as 12 of the 42 chief jurisconsults (şeyhülislam) who occupied the top of the hierarchy during the seventeenth century came from only five families. The proportion rose in the eighteenth century, with half of the 58 chief jurisconsults appointed between 1708 and 1839 coming from 11 families (Zilfi, 1988: 47-48). Moreover, corruption rose to unprecedented levels during the seventeenth century, affecting the delivery of services at the local level and diminishing the reputation of the religious establishment as a whole (Zilfi, 1988: Chapter 1).

The second development was the rising importance of the notables ( $\left.a^{\prime} y \bar{a} n\right)$ in Ottoman provincial society and administration (İnalcık, 1977; Özkaya, 1994). The Ottoman government had long relied on distinguished inhabitants of provincial towns as informal intermediaries between the central administration and general public. These notables assisted the central government by gathering information, enforcing regulations, and providing protection at the local level. The importance of notables grew significantly during the seventeenth century. Acquiring official status, they gained greater political power as recognized representatives of local interests to the central government. 
More important within the context of our model, the notables replaced the military as means of tax collecting/farming in this period. The notables could produce legitimacy from a different source than religious indoctrination. Elected by the local subjects and approved by the ruler, they derived power from representing the people vis-à-vis the government. As Göçek (1996: 62) documents from the Ottoman archives, they built power through political ties with the subjects, "ties that the sultan could not obliterate." As providers of justice, protection, and other public goods, they acquired an enormous capacity to legitimize the ruler, which emanated not from the ruler but from his subjects. While the religious authorities experienced a decline in their ability to confer legitimacy, that of the notables rose during this period. In this context, the notables can be viewed as replacing the military as the second source of legitimacy $(B)$. However, unlike the military, the notables were not complementary with religious authorities indeed, they provided a relatively close substitute as a source of tax collection. Their ability to legitimize depended on their capacity to provide representation and local public goods, not through force or a monopoly over the transmission of knowledge. Hence, unlike the case of military legitimacy, the introduction of the printing press would have had a negligible effect on the tax-collecting efficacy of the notables $(\eta \approx 0)$, as religious indoctrination played at best a trivial role in increasing their ability to collect taxes.

These developments altered the parameters of the ruler's decision on the printing press drastically, tilting the balance in favor of allowing its adoption. As religious authorities suffered a loss in reputation and capacity to offer services at the local level, they also left behind their ability to legitimize the ruler. By actively participating in palace politics in the seventeenth century, they had put their influence at risk, and the establishment was no longer a monolithic entity in supporting the ruler (Zilfi, 1988: 110-21). Estranged from the leaders, members at the 
lower local levels had greater incentive to turn against authority than to promote the sultan's right to rule and collect taxes (Heyd, 1961: 72). In terms of the model, the elasticity of tax revenue with respect to religious legitimacy, $\alpha$, decreased in this period.

In fact, as returns from religious and representational sources of legitimacy changed in the seventeenth and eighteenth centuries, the Ottomans gradually reduced their reliance on religious legitimization and shifted toward the notables to confer legitimacy. The primary instrument of their relationship with the notables was the ruler's prerogative to appoint individuals to collect taxes on behalf of the government. From the seventeenth century onward, the government increasingly appointed local notables as tax farmers, facilitating their rise to prominence in the provinces. By the eighteenth century they had assumed "both de facto and de jure authority formerly exercised exclusively by the governors" (Inalc1k, 1977: 32).

Unlike the case when the military played a more central role in tax collection prior to the $17^{\text {th }}$ century, the acceptance of the printing press no longer had a detrimental effect on the alternative source's (military or notables) ability to legitimize $(\eta \approx 0)$. Combined, the diminished role of religious authorities (which decreased $\alpha$ ) and the rise of the notables as a closely substitutable form of legitimacy (which further decreased $\alpha$ and made $\eta$ less negative), exerted positive pressure on the elasticity of legitimacy with respect to new technology, $\alpha \gamma+\beta \eta-$ to a point where the sultan's optimal choice was to allow the printing press.

\section{INDUSTRIALIZATION IN TSARIST RUSSIA}

The delayed acceptance of industrial technologies in nineteenth-century Russia provides another historical case on which the model sheds light. Prior to the Crimean War (1853-1856), the implementation of Western industrial technologies were actively impeded by Russian political 
authorities. During the reign of Tsar Nicholas I (1825-1855), government finance of industry was severely limited, credit-extension to businessmen was opposed, there were no significant attempts to divert underutilized agricultural capital into industry, and state policy regarding the supply of capital assisted only the landed gentry, not industrialists (Pintner 1964). Most applications for government industrial loans were refused - unless the family applying was wellconnected - and railroads were opposed as a needless risk (Blackwell 1968, p. 175). Although some infant industries (such as iron and cotton textiles) emerged in this period, Russia was an industrial backwater by the eve of the Crimean War.

There were a variety of reasons expressed by government officials for opposition to industrial technologies. Perhaps most importantly, Russia was involved in the first half of the century in a series of wars which were primarily financed through heavy taxation on the peasant masses. Hence, government investment in industry would have put further strain on the already stretched peasantry (and the nobility, who also profited immensely from agriculture), perhaps threatening the viability of the Russian war machine (Blackwell 1968, ch.7). Moreover, the newly-formulated Smithian and Ricardian economic theories, tinged with nationalistic idealizations of Russia as a rural utopia, suggested that Russia should concentrate on agriculture with secure property rights, where its comparative advantage lay (Kingston-Mann 1991). The state also feared that industrialization may concentrate revolution-minded workers in cities and that railways and education would give them the mobility and access to foreign ideas necessary for a revolution (Gregory 1991). Others worried over the effects of having serfs and nobles sit near each other on the same passenger cars (Blackwell 1968).

Despite these expressed reasons for blocking industrialization, which appealed to both the tsar and the Russian masses, a further examination of these arguments suggests that they 
emerged not from the tsar but the bureaucracy and landed nobles, who were overlapping constituencies. The landed nobility had obvious incentives to obstruct industrialization. Most importantly, they suspected (correctly) that the growth of commercial interests would diminish the political and social importance of those who profited from serf agriculture, which was the primary source of income for the landed nobility (Gerschenkron 1965). ${ }^{20}$ They also feared the emergence of protectionist measures, which would benefit infant industries at the expense of agricultural and raw material exporters (Blackwell 1968). ${ }^{21}$ These ideas were clearly expressed by Nicholas I's powerful Minister of Finances, Count E.F. Kankrin, who argued that loans should be given to the gentry and not industrialists because "agriculture still demands from us many improvements, and if the money is not always used purposefully, then, at least, the larger part is, and the support of the gentry is unavoidable for us" (Pintner 1964, 50, italics ours). Pintner (1964) shows in detail that the upshot of Kankrin's (and hence, Nicholas') policies was a massive transfer of funds from the fledgling industrial sector to the gentry, while credit was extremely restricted to the former but freely flowing (sometimes recklessly) to the latter. Kankrin also disapproved of the railroads, noting despairingly that they "increase the equality among the social estates, a subject on which there is much to say in the interest of the so necessary social hierarchy" (Gerschenkron 1965, 710).

Of course, there were many nobles who favored industrialization. Indeed, the industrialization debate was part of a larger $19^{\text {th }}$ century debate between Westernizing and Slavophile (nationalistic, conservative) forces, with the latter going as far as rejecting the idea of

\footnotetext{
${ }^{20}$ It is also true that capital markets were not highly developed in Russia prior to the Crimean War. Thus, even if the tsar or private enterprise wanted to adopt new technologies, financing would have been difficult to find. This, however, cannot explain the active resistance to technology adoption which is at the heart of our model, especially since foreign flows of capital were readily available and were essential to Russia's eventual industrialization at the end of the $19^{\text {th }}$ century (von Laue 1954; Portal 1965).

${ }^{21}$ Blackman (1968, ch. 5) discusses the intellectual and political debate between the "freetraders" and "protectionists" in great detail.
} 
the imperial bureaucracy (Wortman 2006, p. 246-247). Yet, the forces obstructing or proposing delayed industrialization were much stronger amongst the nobles, who sought the preservation of serfdom and the village handicraft industry (Blackwell 1968, ch. 5). ${ }^{22}$

Under the institutions inherited from the old feudal system, the tsars' ability to collect taxes was supported by two sources: the landed nobility $(A)$ and the bureaucracy $(B) .{ }^{23}$ The affairs of the state were run through the bureaucracy, who issued patents and licenses, collected excise taxes, ran the legal system, and managed state enterprises (Blackwell 1968; Pintner 1970; Mosse 1980b; Gregory 1991). The landed nobility, meanwhile, provided valuable services to the tsar such as policing the peasantry, collecting agricultural taxes (the primary source of government revenue in this period), and providing military recruits (Skocpol 1979; Gregory 1991). The Provincial Reform of 1775 and the Charter of the Nobility of 1785 granted the nobility formal representation in numerous public agencies and authority over most aspects of local affairs (Nafziger 2008).

Yet, prior to the Crimean War, the bureaucracy was largely made up of the landed nobility. While there were no land requirements necessary for one to rise through the bureaucracy - education, not land, was the primary requirement for a successful career as a bureaucrat - the landed nobility used their superior access to higher education to gain positions throughout the rather extensive Russian bureaucracy. In a sample of mid-nineteenth century Russian civil service records, Pintner (1970, p. 437, 442) shows that $50 \%$ of the top level

\footnotetext{
${ }^{22}$ For more on many of the forms of the Westernizing versus Slavophile debate, see Wortman (2006).

${ }^{23}$ There were other sources of imperial legitimacy, but it is unlikely that any of these sources would have had an impact on the decision to industrialize. For one, the Orthodox Church was partially under the control of the Tsars and could have been employed as a legitimizing force, as it sanctified his right to rule and was one of the sources of the "scenario of love" bestowed by the Russian people (Wortman 2006). However, there was not a monumental change in the legitimizing relationship that the Church played in this period, and adding it to the model as a source of legitimacy would be an unnecessarily complication. Likewise, the military helped legitimize the Tsar, as can be seen, for example, in the defeat of the Decemberist Insurrection of 1825 . But, like the Church, adding the military as a player in the model would shed little light on equilibrium outcomes. For a cultural history of these and other sources of legitimacy (such as the press) and their relationship with the Tsar, see Wortman (2006).
} 
bureaucrats owned at least 20 serfs and $36 \%$ owned at least 100 serfs, and that amongst bureaucrats, landed nobles were sixteen times more likely to reach the top level of the bureaucracy than were non-noble "servicemen".

This entailed a situation in which the two sources of tax extraction were complementary entities, with no close substitute available. In terms of the model, the elasticity of legitimacy with respect to technology, $\gamma$ and $\eta$, were both negative, as accepting new industrial technologies diminished the nobility's - and hence much of the bureaucracy's - social and political power and thus its ability and willingness to legitimize the tsar. Indeed, Gerschenkron $(1965,723)$ argues that the tsar did not free the serfs or encourage industrialization prior to the Crimean War because "to expropriate the gentry and thus deprive it of its social basis as the landowning class in the country would have left the Imperial government in a most precarious and probably untenable political position." Likewise, Portal $(1965,804)$ suggests that "the interests of the aristocracy were bound up with the existing state of things, which any innovation undermined." Even if the tsar viewed the acceptance of industrial technologies as economically beneficial, he was constrained by the desires of his legitimizing and tax collecting agents.

Russia did not invest heavily in industrial technologies until after the loss of the Crimean War to France, England, the Ottoman Empire, and Sardinia. ${ }^{24}$ After the war, a fundamental "about-face" occurred in Russian industrial policy (Gerschenkron 1962, 1965). The state promoted a series of liberalizing reforms, including large tariffs, attraction of foreign direct investment, construction of state-owned railways, reserving steel, military, and railway equipment contracts for domestic industry, freeing the serfs, and creating the zemstvo

\footnotetext{
${ }^{24}$ There are some scattered counter-examples to this general statement. For example, Tsar Nicholas I was largely in favor of building new railways, particularly those connecting major Russian cities. He supported the building of the famous Tsarskoe Selo line (completed in 1837), which connected St. Petersburg with the summer resorts of the tsars (Blackwell 1968). More importantly, in 1842 he overrode the advice of his ministers and commissioned the construction of a line connecting St. Petersburg and Moscow (Blackwell 1968, ch. 12).
} 
representative assemblies. These actions encouraged the industrial boom of the $1880 \mathrm{~s}$ and led to a high rate of growth in the latter half of the nineteenth century; manufacturing and mining grew by $4.2 \%$ per annum in $1860-1873$, but rose dramatically for $5.8 \%$ per annum in $1874-1887$ and $8.1 \%$ per annum in $1888-1900$ (Goldsmith 1961). ${ }^{25}$

Why did Russian political authorities switch their position regarding industrial technologies after the conclusion of the Crimean War? A popular explanation is that the devastating loss in the Crimean War highlighted Russia's military weakness compared to industrialized Western Europe (Mosse 1955; Gerschenkron 1962, 1965; Blackwell 1968; Skocpol 1979). Towards the end of the war a number of top generals met to discuss the future of the Russian war machine, with General Dmitry Muliutin’s memo “The Danger of Continuing Military Activities in 1856 " clearly spelling out the inability of a non-industrialized country to engage in modern warfare, arguing that Russia could not compete with the "inexhaustible abundance of industrialized Western Europe” (Blackwell 1968, 187). Historians who link the exposing of Russia's military weakness to subsequent industrialization often point to the freeing of the serfs in 1861. This argument, most prominently argued by Gerschenkron $(1962,1965)$ suggests that the civil unrest caused by the defeat in the Crimean War encouraged the freeing of the serfs and the provision of political power to the non-landed classes. This in turn was a necessary precondition for industrialization, as it provided the manpower necessary for an industrial base to thrive. Another similar view provided by Acemoglu and Robinson (2006) suggests that industrialization after the war occurred because the tsar feared political replacement

\footnotetext{
${ }^{25}$ Kahan (1967) argues that the government policies may have been counter-productive, as the high tariffs in particularly stymied domestic demand while limiting competition. Moreover, Kahan argues that tariffs were imposed for revenue purposes, not to spur industrialization. This viewpoint is difficult to reconcile with the internal memo written by Finance Minister Sergei Witte which is quoted in the text.
} 
- that is, an increasingly probable replacement by foreign or domestic threats encouraged the tsar to support industrialization in spite of its negative effects on the landed nobility.

However, much as in the Ottoman case, the effects of military defeat and fear of political replacement cannot explain the timing of the Russian about-face in industrial policy. Even Gerschenkron (1962, 19, italics ours) notes that "unlike the case of Western Europe, [agrarian reforms] did not per se lead to an upsurge of individual activities in [Russia]; and for almost a quarter of a century after the emancipation [of the serfs] the rate of industrial growth remained relatively low. ${ }^{, 26}$ Gerschenkron $(1962,125)$ also suggests that by the 1890 s, "the fear of industrialization, so much in evidence in the 1860s, was gone." While the extension of the rail system beginning in the 1860 s was encouraged primarily as a means of increasing troop mobility and war mobilization (Gerschenkron 1965; Kahan 1967) ${ }^{27}$ pro-industrial policies were largely opposed until the 1880s, decades after the end of the Crimean War. Numerous requests to the bureaucracy proposed by the powerful Russian Industrial Society in the late 1860s and 1870 were delayed and not accepted until the 1880s. Examples of such requests include tariffs on iron, the improvement of canals, the development of a system of industrial statistics, and the abolition of duty-free transit of European goods across the Caucasus and Caspian Sea regions (Owen 1985). Many other requests were simply denied by the bureaucracy in this period (particularly 1869-1873), including refusal to permit mining operations, regulation of the gold industry, and multifarious fines and regulations (Owen 1985).

Hence, any explanation relying on the direct effects of war, political replacement, or the freeing of the serfs suffers from a timing problem: these cataclysmic events occurred in the

\footnotetext{
${ }^{26}$ Gerschenkron $(1962,1965)$ does not ignore the timing problem. He claims that rigidities associated with the postemancipation redemption payments owed by the peasants prevented the free movement of resources. Gregory (1991) argues that the rigidities that Gerschenkron highlights did not exist in actuality.

${ }^{27}$ Kahan (1967) does note, however, that regardless of the degree to which railroads were constructed for military purposes, the large magnitude of social savings associated with the expansion of the railroad system is undeniable.
} 
1850 s and early $1860 \mathrm{~s}$, whereas the pro-industrial shift did not arise until the $1880 \mathrm{~s} .{ }^{28}$ What can explain this massive change in policy from one that was openly antagonistic to Western-style industrialization to one that eventually openly embraced it? More importantly, what can explain the long delay in industrial promotion following the devastating defeat in the Crimean War?

Our model provides a solution. While the fear of political replacement cannot directly explain the timing of the Russian about-face in industrial policy, it did set in motion a series of events that indirectly - and unintentionally - affected the tsar's decision making calculus. The most important change undertaken after the defeat in the Crimean War was the provision of greater political power to the non-landed classes, who threatened to rebel against the tsar (Gerschenkron 1962, 1965). The most prominent example of this power shift was the freeing of the serfs, but another upshot of these changes was a gradual restructuring of the bureaucracy. Throughout the latter half of the nineteenth century, the bureaucracy changed from an institution controlled by landed interests to one representing a wide scope of interests and social classes - often in direct opposition to the landed nobility. This is forcefully argued by Mosse (1980a), who documents the changes in class affiliation of the State Council, a top layer of the Russian bureaucracy who served as the highest legislative and budgetary institution in Russia. ${ }^{29}$ He notes that the portion of hereditary landed Council members fell from $76 \%$ in 1854 to $65 \%$ in 1864 to $54 \%$ in 1874 to $38 \%$ in 1884 , after which it leveled off - a trend that was consistent with the general weakening of the landed nobility following the emancipation of the serfs in 1861 (Mosse 1980a, 1981). ${ }^{30}$

\footnotetext{
${ }^{28}$ Kahan (1967) and Gregory (1991) argue against placing too great of an emphasis on the role that the state played in Russian industrialization. They claim that the tariffs imposed appear to be driven by revenue, not protectionist, concerns, and that state enterprises played only a small role in industrialization.

${ }^{29}$ Council members were appointed, effectively for life, by the tsar. Appointment was prestigious, and the pool from which the tsar had to choose was relegated to those receiving advanced degrees (Mosse 1980a).

${ }^{30}$ These numbers change only slightly if landed is defined as either hereditary or acquired via marriage. The percentage of landed in this case falls from $72 \%$ under Alexander II to 58\% under Alexander III to $48 \%$ under
} 
By the mid-1880s, a distinct cleavage had arisen between the bureaucracy and the landed nobility, largely due to greater access to education for the non-landed elites. Mosse (1981, p. 632) notes that "from at least the middle of the nineteenth century, the top stratum of the Russian bureaucracy had ceased to be tied closely to the Russian system of estates. At the same time, it had divided into a traditional and a developmental sector with interests and aspirations that were basically irreconcilable." By the end of the century, this division had become stark enough that the prominent gentry spokesman Vorontsov-Dashkov cited the need to "liberate the landed nobility from the alien [bureaucracy]" (Mosse 1980a, p. 280). Moreover, the emancipation of the peasantry and the subsequent installment of the zemstvo system took local power away from the landed nobility, providing some level of "local democracy" whereby the non-landed were well represented on boards that made local spending and revenue decisions (Nafziger 2008).

In the latter half of the nineteenth century, the landed nobility lost their dominant position in bureaucratic administration as well as national and local politics. They ceded their ability to affect tax collection on the national level to the senior members of the bureaucracy while also ceding some of their local power (though to a lesser degree) to other classes in the zemstva. This change did not go unnoticed by the leading proponents of industrialization. Perhaps the most important figure in this battle, the powerful Finance Minister Sergei Witte, explicitly favored the appointment of the non-landed classes to the bureaucracy, claiming that it would allow the creation of a new capitalist class consisting of the most industrious landowners and commercial and industrial entrepreneurs (Mosse 1980a). Witte passionately stated the connection between the two in a secret memorandum to the tsar, stating that:

Nicholas II (Mosse 1979). Despite the fact that many of the Councilors were still chosen from the hereditary nobility by the end of the century, the overarching trend was a movement away from the landed nobility within the bureaucracy. 
... it was clear to me that any commercial and industrial policy touching very directly the property interests of the population would always have its defenders and opponents. I considered it my duty to listen to the latter, and I recognized the necessity of alleviating the measures which inevitably brought temporary damage to some (quoted in von Laue 1954, 65).

In terms of the model, this entailed a situation in which the landed nobility $(A)$ and bureaucracy $(B)$ were substitutable entities on the national level, while the nobility lost some of its legitimizing power $(\alpha)$ on the local level. ${ }^{31}$ Since the bureaucracy was no longer run primarily by the nobility, accepting industrial technologies no longer hindered the tsar's ability to collect taxes through the bureaucracy, as they were now close substitutes to the landed nobility. This has been noted at length by two economic historians, whose thoughts are worth quoting:

... having no distinct economic interests, at any rate collectively, and being frequently imbued with egalitarian principles, [non-landed] officials, given a political impetus from the outside ... would be a ready instrument for reform or social change. This was one reason why they were feared and distrusted by the landed gentry (Mosse 1980a, 291).

If Gerschenkron's assessment of Russian state policy is accurate ... then likely the most important state role in Russian industrialization was the abandonment of its anti-industrialization stance. This passive view of the Russian state's role differs dramatically from Gerschenkron's emphasis on the active role of the state in promoting industrialization (Gregory 1991; italics ours).

The key point on which the model sheds light is that Russian industrialization occurred only after a key legitimizing constituency (the landed nobility), who had a vested interest in delaying industrialization, lost its power to legitimize. It was not the case that a new constituency favoring adoption of industrial technologies arose in this period. At best, the non-landed bureaucracy was ambivalent to industrialization, as they were not the primary beneficiaries of a

\footnotetext{
${ }^{31}$ Mosse (1980a) notes that the bureaucracy in general was a stranger to the interests of the landed classes and by the end of the century was viewed as completely separate from the landed.
} 
move towards a more industrial economy. ${ }^{32}$ The model notes that it is not necessary for the legitimizing source to embrace a technology before it is accepted; it must merely not oppose it. Moreover, an increased probability of political replacement (a reduction in $p$ in the model) following the Crimean War cannot explain the timing of the pro-Industrial shift. If anything, the fear of political replacement encouraged a slow transition of power from the landed gentry to the non-landed, and it was only after this transition was complete that the elements opposing industrialization were sufficiently weak to delay the onset of industrialization.

In terms of the model, the decrease of the landed gentry's interests in the bureaucracy and the rise of the non-landed in the zemstva resulted in a decrease in the legitimizing power of the landed classes $(\alpha)$ and an increase in the legitimizing power of the non-landed classes $(\beta)$. The technology-specific elasticity associated with the landed nobility $(\gamma)$ remained highly negative, but the technology-specific elasticity associated with the non-landed bureaucracy $(\eta)$ increased from a highly negative value (when the bureaucracy was largely run by landed interests) to near zero. This had the effect of increasing elasticity of legitimacy with respect to new technology, $\alpha \gamma$ $+\beta \eta$. Though it is possible that this term was still negative, the model indicates that a sufficiently small negative value (in absolute terms) of the elasticity of legitimacy can encourage adoption of the technology, as the ruler will sacrifice some legitimacy for an increased surplus.

The logic of the model sheds new light previous theories of Russian industrialization. As quoted above, Paul R. Gregory (1991) - in his critique of Gerschenkron - suggests the possibility that the role of the state (bureaucracy) in the acceptance of industrialization and industrial technologies may have merely been a passive one of non-opposition. The model

\footnotetext{
${ }^{32}$ It is possible that, given the positive economic rents available through industrialization, acceptance of industrialization enhanced the bureaucracy's tax collecting ability. However, there is little evidence that this was a key factor in the decision to industrialize. More importantly, Gregory (1991) notes that the late-19 ${ }^{\text {th }}$ century bureaucracy did indeed appear to grant licenses on the basis of merit rather than some systemic vested interest.
} 
indicates that this is precisely what was required for the acceptance of industrialization: the emergence of a source of legitimacy without a stake in preventing its acceptance. Hence, when the tsar was able to gain more tax revenue in the 1880s from sources outside the landed nobility's control than it previously could, industrialization blossomed in spite of its detrimental effect on landed interests.

\section{CONCLUSION}

To reiterate the question posed at the beginning of this paper: why and when are new technologies accepted or not accepted? In this paper, we analyze both the acceptance and nonacceptance of technologies in the Ottoman Empire (printing) and Tsarist Russia (industrialization). We discuss each of these cases in the light of a simple political economy model which suggests that rulers may choose to reject new, productivity-enhancing technologies if these technologies sufficiently damage their ability to be legitimized (through religious authorities, landed nobility, the military, and the like). However, when substitute forms of legitimacy emerge that are not harmed by the new technology, rulers have more incentive to accept new technologies. Even if the substitute source of legitimacy does not actively advocate for the adoption of the new technology, the likelihood of adoption rises merely if the substitute source's ability to legitimize is not harmed by its acceptance.

More specifically, the model suggests that Ottoman sultans initially forbade the printing press because it would have undermined religious authorities, who were their primary source of legitimacy. However, when a new source of legitimacy emerged in the eighteenth century (the notables), the sultans were willing to permit the press, as their ability to collect tax revenue was less dependent on religious indoctrination. Similarly, the model sheds light on the Russian tsars' 
decision not to industrialize prior to or directly after the Crimean War, suggesting that industrialization would have roused opposition from the landed gentry, whose interests were in agriculture. The gentry made up much of the bureaucracy and thus controlled the two institutions which legitimized the tsar's right to tax: the 'feudal' system, which collected agricultural taxes, and the bureaucracy, which collected all other taxes. The dynamics changed after the Crimean War, but only through the war's effect on the makeup of the bureaucracy. Once non-landed interests grew in importance within the bureaucracy, the tsar obtained a form of legitimacy that was not harmed by industrialization. A stylized version of these histories in the context of the model is summarized in Table 2.

\section{[INSERT TABLE 2 HERE]}

In sum, this paper employs a simple political economy to analyze the adoption and nonadoption of new technologies. It complements other works on political losers blocking technology adoption (Acemoglu and Robinson 2000, 2006; Chaudhry and Garner 2006, 2007) by accounting for the institutional conditions that provide incentives for rulers to adopt or block technologies. In doing so, it sheds new light on the rejection - and eventual acceptance - of new technologies in different epochs under differing institutional settings.

\section{REFERENCES}

Acemoglu, Daron, and James A. Robinson. "Political Losers as a Barrier to Economic Development." American Economic Review 90 (2000): 126-130. . "Economic Backwardness in Political Perspective." American Political Science Review 100 (2006): 115-131.

Adıvar, A.A. Osmanlı türklerinde ilim, 2. tabı edn, İstanbul: Maarif matbaası, 1943. 
Atiyeh, G.N. The book in the Islamic world: the written word and communication in the Middle East. Albany: State University of New York Press, 1995.

Baten, J. \& van Zanden, J.L. "Book Production and the Onset of Modern Economic Growth." Journal of Economic Growth 13 (2008): 217-235.

Baysal, J. Mü̈eferrikadán Birinci Mesfutiyete kadar Osmanlı Türklerinin bastıkları kitaplar, 1. Istanbul: bask1 edn, 1968.

Bellettini, Giorgio, and Gianmarco I.P. Ottaviano. "Special Interests and Technological Change." Review of Economic Studies 72 (2005): 43-56.

Blackwell, William L. The Beginnings of Russian Industrialization, 1800-1860. Princeton: Princeton University Press, 1968.

Bridgman, Benjamin R., Igor D. Livshits, and James C. MacGee. "Vested interests and technology adoption.” Journal of Monetary Economics 54 (2007): 649-666.

Canton, Erik J.F., Henri L.F. de Groot, and Richard Nahuis. "Vested interests, population ageing and technology adoption." European Journal of Political Economy 18 (2002): 631-652.

Chaudhry, Azam, and Phillip Garner. "Political Competition Between Countries and Economic Growth." Review of Development Economics 10 (2006): 666-682.

. "Do Governments Suppress Growth? Institutions, Rent-Seeking, and Innovation Blocking in a Model of Schumpeterian Growth.” Economics \& Politics 19 (2007): 35-52.

Coşgel, Metin M., Miceli, Thomas, and Ahmed, Rasha. "Law, state power, and taxation in Islamic history." Journal of Economic Behavior and Organization 71:3 (2009): 704-717.

Coşgel, Metin M., Miceli, Thomas, and Rubin, Jared. "The Political Economy of Mass Printing: Legitimacy, Revolt, and Technology Change in the Ottoman Empire." Working Paper, 2011.

Darling, L.T. Revenue-raising and legitimacy: tax collection and finance administration in the Ottoman Empire, 1560-1660. New York: Brill, 1996.

David, Paul A. "Clio and the Economics of QWERTY.” American Economic Review 75 (1985): 332-337.

Dittmar, Jeremiah. "Ideas, Technology, and Economic Change: The Impact of the Printing Press.” Quarterly Journal of Economics 126 (2011): 1133-1172.

Eisenstein, E.L. The printing press as an agent of change: communications and cultural transformations in early modern Europe. Cambridge: Cambridge University Press, 1979. 
Gerçek, S.N. Türk matbaaciliği. Istanbul: Devlet basimevi, 1939.

Gerschenkron, Alexander. Economic Backwardness in Historical Perspective: A Book of Essays. Cambridge: Harvard University Press, 1962.

. "Agrarian Policies and Industrialization: Russia 1861-1917". In The Cambridge Economic History of Europe. Vol. 6. H.J. Habakkuk and M. Postan, Eds. Cambridge: Cambridge University Press, 1965, 706-800.

Göçek, F.M. East encounters West: France and the Ottoman Empire in the eighteenth century. New York: Oxford University Press, 1987.

. Rise of the bourgeoisie, demise of empire: Ottoman westernization and social change. Oxford: Oxford University Press, 1996.

Goldsmith, Raymond W. "The Economic Growth of Tsarist Russia 1860-1913.” Economic Development and Cultural Change 9 (1961): 441-475.

Gregory, Paul R. "The role of the state in promoting economic development: the Russian case and its general implications," In: Patterns of European Industrialization: The nineteenth century, Richard Sylla and Gianni Toniolo (Eds.). London: Routledge, 1991.

Greif, Avner. "The Islamic Equilibrium: Legitimacy and Political, Social, and Economic Outcomes." Working Paper, 2002.

Heyd, U. "The Ottoman 'Ulemā and Westernization in the Time of Selīm III and Mahmūd II." Scripta Hierosolymitana 9 (1961): 334-357.

Hoppe, Heidrun C. "The Timing of New Technology Adoption: Theoretical Models and Empirical Evidence.” The Manchester School 70 (2002): 56-76.

İnalcık, H. "Centralization and Decentralization in Ottoman Administration" in Studies in Eighteenth Century Islamic History, eds. T. Naff \& R. Owen, Carbondale: Southern Illinois University Press, 1977.

Kahan, Arcadius. "Government Policies and the Industrialization of Russia." Journal of Economic History 27 (1967): 460-477.

Katz, Michael L., and Carl Shapiro. "Technology Adoption in the Presence of Network Externalities.” Journal of Political Economy 94 (1986): 822-841.

Kingston-Mann, Esther. "In the Light and Shadow of the West: The Impact of Western Economics in Pre-Emancipation Russia." Comparative Studies in Society and History 33:1 (1991): 86-105. 
Krusell, Per, and José-Víctor Ríos-Rull. "Vested Interests in a Positive Theory of Stagnation and Growth.” Review of Economic Studies 63 (1996): 301-329.

Kut, G.A. "Matba'a. 2. In Turkey" in The Encyclopaedia of Islam, New, edn, Brill, Leiden, pp. 799-803, 1991.

Landes, David S.. The Wealth and Poverty of Nations: Why Some Are So Rich and Some so Poor. New York: W.W. Norton, 1998.

Mokyr, Joel. The Lever of Riches: Technological Creativity and Economic Progress. Oxford: Oxford University Press, 1990.

. "Technological Inertia in Economic History." Journal of Economic History 52 (1992): 325-338.

. "The Political Economy of Technological Change: Resistance and Innovation in Economic history." In: Maxine Berg and Kristin Bruland, eds., Technological Revolutions in Europe, Cheltenham: Edward Elgar Publishers, 1998, pp. 39-64.

Mosse, W.E. "How Russia Made Peace September 1855 to April 1856." Cambridge Historical Journal 11 (1955): 297-316.

. "Aspects of Tsarist Bureaucracy: Recruitment to the Imperial State Council 1855-

1914." Slavonic and East European Review 57 (1979): 240-254.

. "Aspects of Tsarist Bureaucracy: The State Council in the Late Nineteenth Century." English Historical Review 95 (1980a): 268-292.

. "Russian Bureaucracy at the End of the Ancien Regime: The Imperial State Council, 1897-1915.” Slavic Review 39 (1980b): 616-632.

. "Bureaucracy and Nobility in Russia at the End of the Nineteenth Century." Historical Journal 24 (1981): 605-628.

Mystakidis, B.A., "Hükümet-i Osmaniye Tarafından İlk Tesis Olunan Matbaa ve Bunun Sirayeti,"Türk Tarih Encümeni Dergisi I(1911): 322-28, 451-58.

Nafziger, Steven. "Democracy Under the Tsars? The Case of the Zemstvo.” Working Paper, 2008.

Neumann, Christoph K. "Political and Diplomatic Developments," In The Cambridge History of Turkey: Volume 3, The Later Ottoman Empire, 1603-1839. S. Faroqhi, Ed. Cambridge: Cambridge University Press, 2006, 44-64.

Olson, Mancur. The rise and decline of nations: economic growth, stagflation, and social rigidities. New Haven: Yale University Press, 1982. 
Owen, Thomas. "The Russian Industrial Society and Tsarist Economic Policy, 1867-1905." Journal of Economic History 45 (1985): 587-606.

Özkaya, Y. Osmanli Imparatorlugu'nda âyânlik. Ankara: Türk Tarih Kurumu Basimevi, 1994.

Parente, Stephen L., and Edward C. Prescott. "Monopoly Rights: A Barrier to Riches." American Economic Review 89 (1999): 1216-1233.

Pintner, Walter M. "Government and Industry during the Ministry of Count Kankrin, 18231844.” Slavic Review 23 (1964): 45-62.

. "The Social Characteristics of the Early Nineteenth-Century Russian Bureaucracy." Slavic Review 29 (1970): 429-443.

Portal, Roger. "The Industrialization of Russia." In The Cambridge Economic History of Europe. Vol. 6. H.J. Habakkuk and M. Postan, Eds. Cambridge: Cambridge University Press, 1965, 801-874.

Robinson, F. "Technology and Religious Change: Islam and the Impact of Print." Modern Asian Studies, 27 (1993): 229-251.

Rubin, Jared. "Institutions, the Rise of Commerce, and the Persistence of Laws: Interest Restrictions in Islam \& Christianity.” Economic Journal, forthcoming, 2011.

Sabev, O. İbrahim Müteferrika ya da İlk Osmanli Matbaa Serüveni (1726-1746): Yeniden Degerlendirme. Istanbul: Yeditepe, 2006.

Savage-Smith, E. "Islam" in The Cambridge history of science. Vol. 4. Eighteenth-century science, ed. R. Porter, Cambridge University Press, Cambridge ; New York, 2003.

Skocpol, Theda. States and Social Revolutions: A Comparative Analysis of France, Russia, and China. Cambridge: Cambridge University Press, 1979.

Szyliowicz, J.S. "Functional Perspectives on Technology: the Case of the Printing Press in the Ottoman Empire." Archivum Ottomanicum 11 (1986): 249-259.

Von Laue, T.H. "A Secret Memorandum of Sergei Witte on the Industrialization of Imperial Russia.” Journal of Modern History 26 (1954): 60-74.

Wortman, Richard S. Scenarios of Power: Myth and Certmony in Russian Monarchy. Princeton: Princeton University Press, 2006.

Zilfi, M.C. The politics of piety: the Ottoman ulema in the Postclassical Age (1600-1800). Minneapolis: Bibliotheca Islamica, 1988. 


\section{TABLES}

Table 1: Effect of Parameter Changes on Technology Acception and Rejection

\begin{tabular}{c|c|c}
$\begin{array}{c}\text { Parameter } \\
\text { Conditions }\end{array}$ & $\begin{array}{c}\text { Likelihood of } \\
\text { Technology } \\
\text { Acceptance } \\
\text { Increasing In: }\end{array}$ & $\begin{array}{c}\text { Likelihood of } \\
\text { Technology } \\
\text { Rejection } \\
\text { Increasing In: }\end{array}$ \\
\hline$\gamma>0 ; \eta>0$ & $\begin{array}{c}\text { Always } \\
\text { Accept }\end{array}$ & Never Reject \\
$\gamma>0 ; \eta<0$ & $\alpha, \gamma, \eta$ & $\beta$ \\
$\gamma<0 ; \eta>0$ & $\beta, \gamma, \eta$ & $\alpha$ \\
$\gamma<0 ; \eta<0$ & $\gamma, \eta$ & $\alpha, \beta$ \\
\hline
\end{tabular}

Accept Technology When: $\alpha \gamma+\beta \eta \geq \varepsilon^{*}$

Reject Technology When: $\alpha \gamma+\beta \eta<\varepsilon^{*}$

**When $\gamma<0$ or $\eta<0$, technology affects

legitimacy less (in absolute terms) following an increases in either of these parameters 
Table 2: Parameter Changes and Technology Acceptance

\begin{tabular}{|c|c|c|c|c|c|}
\hline & \multirow[b]{2}{*}{$\begin{array}{l}A: \\
B:\end{array}$} & \multicolumn{2}{|c|}{$\begin{array}{c}\text { Ottoman Printing } \\
\text { Technology }\end{array}$} & \multicolumn{2}{|c|}{$\begin{array}{c}\text { Russian } \\
\text { Industrialization }\end{array}$} \\
\hline & & \multicolumn{2}{|c|}{$\begin{array}{c}\text { Religious Authority } \\
\text { Military/Notables }\end{array}$} & \multicolumn{2}{|c|}{$\begin{array}{c}\text { Landed Nobility } \\
\text { Bureaucracy }\end{array}$} \\
\hline Parameter & Interpretation & $\begin{array}{l}15 \text { th- } 17 \text { th } \\
\text { Centuries }\end{array}$ & $\begin{array}{c}\text { 19th } \\
\text { Century }\end{array}$ & Pre-1880s & $1880 \mathrm{~s}$ \\
\hline$\alpha$ & $\begin{array}{l}\text { Elasticity of tax } \\
\text { collection w.r.t. } \\
\quad \text { input of } A\end{array}$ & $>0$ & $\downarrow$ & $>0$ & $\downarrow$ \\
\hline$\gamma$ & $\begin{array}{c}\text { Technology- } \\
\text { specific elasticity } \\
\text { associated with } A\end{array}$ & $<0$ & same & $<0$ & same \\
\hline$\beta$ & $\begin{array}{l}\text { Elasticity of tax } \\
\text { collection w.r.t. } \\
\text { input of } B\end{array}$ & $>0$ & $\uparrow$ & $>0$ & $\uparrow$ \\
\hline$\eta$ & $\begin{array}{c}\text { Technology- } \\
\text { specific elasticity } \\
\text { associated with } B\end{array}$ & $<0$ & $\approx 0$ & $<0$ & $\approx 0$ \\
\hline
\end{tabular}

